\title{
Using Lexical Phrases to Help with the Flow of Deliverance in Public Speaking
}

\author{
Sangrawee Donkaewbua \\ English Language Studies Department, Rajabhat Mahasarakham University, Mahasarakham Province, Thailand
}

Received July 19, 2021; Revised September 23, 2021; Accepted October 17, 2021

\section{Cite This Paper in the following Citation Styles}

(a): [1] Sangrawee Donkaewbua , "Using Lexical Phrases to Help with the Flow of Deliverance in Public Speaking," Universal Journal of Educational Research, Vol. 9, No. 11, pp. 1866 - 1876, 2021. DOI: 10.13189/ujer.2021.091106.

(b): Sangrawee Donkaewbua (2021). Using Lexical Phrases to Help with the Flow of Deliverance in Public Speaking. Universal Journal of Educational Research, 9(11), 1866 - 1876. DOI: 10.13189/ujer.2021.091106.

Copyright $(2021$ by authors, all rights reserved. Authors agree that this article remains permanently open access under the terms of the Creative Commons Attribution License 4.0 International License

\begin{abstract}
Public speaking in Thailand especially in Thai youth who uses English as a second language still has lots of problems and needs some major development. The researcher noticed after weeks of observation that there were lots of problems in speaking of all the 45 students studying in the public speaking course since they paused too many times while speaking, each pause took a long time and they paused at the wrong places. This pausing manner made speaking sound unnatural even if it was accurate. Since the meaning of the message was disturbed by pausing wrongly, the researcher would like to try a new teaching method by teaching how to chunk their words while speaking by using lexical phrases as language input in order to help develop efficient lexical retrieval. This research aims at studying the effects that lexical phrases have on public speaking. The analysis of the study uses both quantitative and qualitative research by analyzing through a new teaching method in public speaking that is using lexical phrases as a means to keep the flow of deliverance in public speaking going. Lexical phrases were presented to language learners in several ways. Some are presented through mini lectures and some through simulated public speaking situations or activities. These include speaking connectors to buy time in speaking. There are three out of 45 research participants participating in this research because these three are advanced students which were chosen by their grades in the previous year in speaking class. The data were collected by individual elicitation interviews by using descriptive statistics. As a result, lexical phrases offer language learners the opportunity of fluent production. Furthermore, lexical phrases offer less likelihood of producing deviant
\end{abstract}

language because lexical phrases come ready made.

Keywords Lexical Phrases, Pause, Chunking

\section{Introduction}

Research on lexical phrases can be classified into 3 categories. They are the exploration of the theoretical principles, application and learning [1], the exploration of the relationship between second language input or input capability and strategy [2] [3], the exploration of the use of lexical phrases in teaching practice, both qualitative and quantitative [4] [5] [6]. This research will look at both perspectives of the study of qualitative and quantitative lexical phrases.

The researcher noticed after weeks of observation that there were lots of problems in speaking of all the 45 students studying in the public speaking course since they paused too many times while speaking, each pause took a long time and they paused at wrong places. This pausing manner made speaking sound unnatural even if it was accurate. From preliminary interviews after the observation, the 3 target research participants stated that they paused the way they did because they were trying to find the right structure to give the exact messages. They also stated that they could not recall what to say next, despite doing many rehearsals. As a result, they paused too many times and each pause took a long time. With this condition that they went through, it seemed that the cause of the problem was the lack of lexically efficient language 
retrieval to fill out these pauses. Many theories of language performance suggested that this problem occurred because vocabulary and structure were stored redundantly in memory. The language was stored so scattered as individual morphemes, parts of speech phrases or even as longer memorized chunks of speech [7]. The scattered storage caused foreign language learners' difficulties with the process of selection and retrieval. As a result, they tend to pause at the wrong place.

Native speakers or fluent speakers do not pause in mid-clause [8]. Doing so made the message lose its meaning. In public speaking, this may even cause annoyance and present a lack of confidence on the speakers' side. This is really unacceptable as public speaking is a way of making your ideas public by sharing them with other people and of influencing other people as well [9].

Since the meaning of the message was disturbed by pausing wrongly, the researcher would like to try a new teaching method by teaching how to chunk their words while speaking by using lexical phrases as language input in order to help develop efficient lexical retrieval. Lexical phrases extend individual words to multi-words or phrases that exist as a single unit in the meaning system of a language [10]. As a result, lexical phrases offer language learners the opportunity of fluent production. Furthermore, lexical phrases offer less likelihood of producing deviant language because lexical phrases come readymade.

\subsection{Statement of the Problem}

The researcher noticed after weeks of observation that there were a lot of problems in speaking, mainly since they paused too many times while giving a speech, each pause took a long time. They also pause at the wrong places. This pausing manner made speaking sound unnatural even if it was accurate. From preliminary interviews after the observation of the problem, the target research participants stated that they paused the way they did because they were trying to remember their scripts for they were given speech topics to prepare for class each week. As a result, they paused too many times and for a long time. With this condition that they went through, although with many speech rehearsals, it seemed that the cause of the problem was the lack of lexical efficient language retrieval. Many theories of language performance [7] suggested that this problem occurred because vocabulary and language structure were stored redundantly in memory. The scattered storage gave foreign language learners difficulties with language retrieval. As a result, they tend to pause at the wrong place such as pausing in mid-clause where native speakers usually do not pause. For public speaking, according to [9], pause can signal the end of a thought unit, give an idea time to sink in, and lead dramatic impact to a statement. He suggested that when pausing, make sure to pause at the end of thought units and not in the middle. Most importantly, he suggested not filling the silence with "uh," "er," or "um" which these students do.
These sounds are annoying. They can create negative perceptions about the speaker's intelligence by making them appear deceptive. If the students know words to fill in the blank to let the train of thoughts come through, this will make public speaking a good one.

\subsection{Rationale of the Study}

Native speakers and fluent speakers do not pause in mid-clause [8] because the message will lose its meaning. This is because the message has been cut to different units of meaning by pausing wrongly. Since the meaning of the message was disturbed by pausing wrongly, the researcher would like to try a teaching method by teaching students to chunk their words while giving speech by using lexical phrases. It is hoped that this will help them develop efficient lexical retrieval and buy them some time to think ahead as they give the speech because they are not speaking word by word.

Lexical phrases extend individual words to multi-words or phrases that exist as a single unit in the meaning system of a language. Their form and function occur more frequently and are more idiomatically determined in meaning [10]. According to statistics, $90 \%$ of speaking communication was realized by lexical phrases [11]. Schmidt thinks that language learning is an accumulation of lexical phrase [12]. As a result, lexical phrases offer the learners the opportunity of fluent production with less likelihood of producing deviant language because lexical phrase come readymade. Using lexical phrases as a speaker will permit more direct attention to the larger structure of the discourse. By doing so, the learners may tend to pause at clause boundaries and thus pause in the right places.

It is very likely that lexical phrases affect speaking ability because they are available as a repertoire of elements which may be used in the actual conversation to achieve a degree of real time fluency. It is important to improve fluency by teaching lexical phrases because lexical phrases help with language storage and retrieval. In this way, teaching lexical phrases for public speaking may solve the problems of pausing too many times, despite doing many speech rehearsals before coming to class to give the speech. Because lexical phrases are taught as meaningful units in language, they also tend to solve pausing at the wrong places.

This research investigates the effects of teaching lexical phrases in public speaking. With this strategy, the researcher hopes to determine whether the learners will pause more at the right place through the training of speaking by using lexical phrases. The attempt is to try to get the student away from speaking word by word but in lexical phrases meaning units instead. This study attempts to answer the following question: What effects do teaching lexical phrases have on public speaking? 


\section{Literature Review}

\subsection{Definition of Lexical Phrases}

Lexical phrases are regarded as

... a sequence, continuous or discontinuous, of words or other meaning elements which appears to be prefabricated, stored and retrieved wholly from the memory at the time of use, rather than being subject to generation or analysis by the language grammar...[13]

Lexical phrases are defined as

... multi-word phenomena that exist somewhere between the traditional poles of lexicon and syntax, conventionalized form or function composites that occur more frequently and are more idiomatically determined in meaning that language which is put together each time ... [10]

\section{Lexical phrases also refer to}

...a unit of clause length or longer whose grammatical form is a standard label for a culturally recognized concept, a term in the language ...[8]

From the various definitions, the researcher decided that the working definition for this research is that lexical phrases are individual words extended to the multi-word of phrases whose unity is based on the meaningful units. The form of lexical phrases that are taught to the students presented from completely fixed lexical phrases to freer lexical phrases is as follows:

1. Sentence heads that can be completed in many ways. From the listeners' perspective, lexical phrases announce the topic of conversations so that the listeners can focus attention, for example, Today, I would like to talk about...

2. Extended frames of the opening of the speech. From the listeners' perspective, lexical phrases announce that the speaker wants to start the speech, for example, how do you do? I am ...

\subsection{The Advantages of Using Lexical Phrases in Speaking in General}

Many theories of language performance suggest that the problems of pausing too many times, each pause taking too long and pausing at the wrong place occur because vocabulary and the structure are stored redundantly in memory [7]. These problems cause barriers to communication because the meaning has been divided into the wrong grouping of meaning deliverance. Lexical phrases hopefully could help solve the students' problem as stated because lexical phases help the learners develop efficient lexical retrieval.

The effect that lexical phrases are claimed to have on the process of speaking is that they become the raw data which help the language learners to begin to perceive patterns, morphology, and those other features of language traditionally thought of as grammar. Within such a model of language learning, lexical phrases are claimed to be the primary source by which the syntactic system is mastered [14].

[15] believes that language production consists of piecing together "the readymade units" appropriate for a particular situation. Comprehension relies on knowing which of these patterns come afterwards in these situations [15]. [16] also says that we are not original in using language. From his observation, much of what we say is claimed to consist of prefabricated multi-word items or lexical phrases [16]. Therefore, teaching lexical phrases as units of meaningful language is claimed to be parallel with the language storage and language processing. This will hopefully help with language retrieval and thus lead to fluency without leaving behind communication correctness [17].

Lexical phrases affect speaking ability in general because they are claimed to be available as a repertoire of elements which may be used in actual conversation to give speeches to achieve a degree of real time fluency. The aspects of fluency that this research is focusing on are having a reasonable fast and steady speech without too much hesitation. Using lexical phrases as a speaker is claimed to permit more direct attention to a larger structure of the discourse, rather than continuing to focus on individual words as they are produced and thus solve the problem of getting learners to pause at the right places. In Lewis's view, fluency is claimed to be largely achieved by combining chunks of lexical phrases, reducing processing difficulty.

For the quality of the produced language, lexical phrases are claimed to allow more time for speakers to think ahead and make fine tuning of words and phrases they want to produce in their utterances, which will make the message sound much more native like. This allows the speaker time to formulate the utterance further [18]. Lexical phrases are also claimed to help to get speakers to produce fluent multi-clause utterances or groups of words that form grammatical units [8]. It is also claimed to prevent producing deviant language because lexical phrases come readymade. These statements explain themselves on how important and how useful it is likely to be adding lexical phrases into each and every speaking lesson including public speaking. The teaching of lexical phrases is a supplement of the present foreign language teaching method which makes the purpose of teaching and study becomes more concrete [19]. Teachers can arrange a series of activities which are in the form of input, internalization and output. In this way, the ability of using lexical phrases can be strengthened as well as the competence of grammar and pragmatic can be improved.

\subsection{The Similarities between Public Speaking and Speaking in General}

The similarities between public speaking and speaking in general are: 
1. Both organize thoughts logically. Both talk to their listeners systematically, step by step. The message is organized.

2. Both tailor the message to the listener. The same exact word and method cannot be used to deliver the same information to different audiences, for example, of different ages.

3. Both aim at telling the story for maximum impact. Speakers of both public speaking and speaking in general carefully build up the story telling, adjusting words and tone of voice to get the best effect the speaker wants.

4. Both adapt to the listeners' feedback. In common circumstances, whenever you talk with someone, you are aware of the listeners' facial and physical reactions.

In many ways, public speaking requires the same qualities used in speaking in general. Most people who communicate well in daily conversation can learn to communicate just as well in public speaking. By the same token, training in public speaking can make you a better speaker in general as well.

\subsection{The Differences between Public Speaking and Speaking in General}

Despite the similarities, public speaking and speaking in general are not identical. The major concern is the size of audiences. As the size of the audiences grows, the manner which the content is delivered will change. Three major differences are:

1. Public speaking is more structured. Public speaking is usually imposed on strict timing. In most cases, the situation does not allow listeners to interrupt with questions or commentary. In public speaking, the speaker must accomplish the purpose in the speech itself. In preparing a speech, the speaker must anticipate questions that might arise in the minds of the audiences and answer them in the speech. Consequently, public speaking demands more planning and preparation than speaking in general.

2. Public speaking requires the use of more formal language. The acquaintance with the audiences is no exception in public speaking. Slang, jargon, and bad grammar are something to be avoided in public speaking because listeners usually react negatively to speakers who do not elevate and polish their language when addressing their speeches.

3. Public speaking requires a different method of delivery. When conversing informally, most people talk quietly, speaking phrases such as you know what I mean, adopt a casual posture, and use vocalized pauses such as uh, um, er. However, effective public speakers, adjust their voices to the content being presented to emphasize and create impact where needed. Furthermore, the speakers adjust their voices to be heard clearly throughout the audience. They also assume a more erect posture. Professionally as they come, they try to avoid distracting mannerisms and verbal habits.

With practice, these differences between public speaking and speaking in general can be mastered and expanded.

\subsection{What is Public Speaking?}

Public speaking is a way of making your ideas public by sharing them with other people and of influencing other people [9]. Throughout history, people have used public speaking as a means of communicating. During modern times, many men and women around the globe have spread their ideas and influence through public speaking.

There are four basic methods of delivering a speech:

1. Reading from a manuscript: Certain speeches must be delivered word for word, according to a prepared manuscript. In such situations, absolute accuracy is essential.

2. Reciting a memorized text: In this speech, memory is paramount. Be sure to memorize it well so throughout the speech you will be able to concentrate on the audience.

3. Speaking impromptu: In this speech, it is delivered with little or no immediate preparation.

4. Speaking extemporaneously: Extemporaneous speech is carefully prepared and practiced in advance. This kind of public speaking will be the focus of this study.

In presenting the speech, the extemporaneous speaker uses only a set of brief notes or speaking outlines to guide the memory. The exact wording is chosen at the moment of delivery. Each time the speaker practices, the wording will be slightly different. As the speaker practices the speech over and over, the best way to present will emerge. The extemporaneous method has several advantages over other kinds of speech in that:

1. It gives more precise control over thoughts and language than does impromptu speaking;

2. It offers greater spontaneity and directness than does speaking from memory or from a full manuscript;

3. It is adaptable to a wide range of situations;

4. It encourages the conversational quality audiences to look for in speech delivery, meaning that no matter how many times a speech has been rehearsed, it still sounds spontaneous to the audience.

\subsection{Public Speaking on Pauses}

One major concern in any speech class is stage fright. Instead of sounding vibrant, they come across as wooden and artificial. They falter over words, speak too quickly or too slowly. They may even speak in monotone, marching through the speech without even glancing at their 
audience. Even worse, they pause in the wrong places. According to [9], pause in public speaking can signal the end of thought unit, give an idea time to sink in, and lead dramatic impact to a statement. He suggested that when pausing, make sure to pause at the end of thought units and not in the middle of them. Most importantly, he advises not to fill the silence with uh, er or um. These sounds are annoying for public speaking. They create negative perceptions about the speaker's intelligence by making them appear deceptive.

\section{Research Methodology}

\subsection{Public Speaking at Rajabhat Mahasarakham University}

Public speaking is taught at Rajabhat Mahasarakham University in a 90-minute period, once-a-week class. It is a compulsory course taken by English majors, Business English majors and Education students majoring in teaching English. The students are introduced to 4 basic types of speeches:
1. An informational speech which provides information to the listeners.

2. A persuasive speech which is meant to persuade its listeners to do something or influence their opinion in some way.

3. A demonstrative speech which explains how to do something.

4. An entertaining speech which is meant to entertain its listeners. It will often make the audience laugh or identify with the speaker.

\subsection{Research Participants}

The research was conducted with 3 research participants selected from a public speaking class at Rajabhat Mahasarakham University consisted of 45 students. In order to control several variables such as level of proficiency, only those students with average grades in English from their overall GPA from the previous year were considered. Of these, the 3 research participants were selected at random from the average grade students since this research dealt with speaking skill which is the hardest and highest level of the 4 language skills [20].

Table 1. Materials Used in Each Speech from Speech 1 to 12

\begin{tabular}{|c|c|c|}
\hline Speech & Type of Speech & Samples of Topics to Choose from \\
\hline $1-3$ & $\begin{array}{l}\text { Informational } \\
\text { Speech }\end{array}$ & $\begin{array}{l}\text { - speaking about your hobbies } \\
\text { - talking about your plans or dream } \\
\text { - introducing your research } \\
\text { - a travelogue about a place you have visited } \\
\text { - explaining a new technology } \\
\text { - giving advice about buying something } \\
\text { - current trends in... } \\
\text { - the future of... } \\
\text { - the history of... } \\
\text {-the origin of ... }\end{array}$ \\
\hline $4-6$ & Persuasive Speech & $\begin{array}{l}\text { - Should students' textbooks be replaced by notebook computers? } \\
\text { - Should students have to wear uniforms? } \\
\text { - Should government colleges be free to attend? } \\
\text { - Should same sex marriage be allowed? } \\
\text { - Should Thailand build nuclear reactors? } \\
\text { - Is violence on tv bad for children? } \\
\text { - What is more important, ... or...? } \\
\text { - Do you agree or disagree with ... ? Why? }\end{array}$ \\
\hline $7-9$ & $\begin{array}{c}\text { Demonstrative } \\
\text { Speech }\end{array}$ & $\begin{array}{l}\text { - How to make something } \\
\text { - How to make a paper airplane } \\
\text { - How to build a house } \\
\text { - How to cook Thai food } \\
\text { - How to make a professional video } \\
\text { - How to do something } \\
\text { - How to play guitar } \\
\text { - How to paint } \\
\text { - How to plan a party } \\
\text { - How to learn a foreign language } \\
\text { - How to repair something } \\
\text { - How something works }\end{array}$ \\
\hline $10-12$ & Entertaining Speech & $\begin{array}{l}\text { - How to impress a girl (or boy) you like } \\
\text { - What to do when you are bored } \\
\text { - Things I learned from the movies } \\
\text { - Things men (or women) would never say } \\
\text { - Problem solving in an entertaining way } \\
\text { - Things not to put on Facebook } \\
\text { - Words in English that sound funny in Thai } \\
\text { - Ten ways to cheat on an exam } \\
\text { - Unusual incidents }\end{array}$ \\
\hline
\end{tabular}




\subsection{Material Used}

The teaching material used is an in-house book with 4 kinds of basic public speaking for the students to practice on. They are informational speech, persuasive speech, demonstrative speech and entertaining speech. Samples of topics to choose from are given but not forced on the speaker to choose from. They could talk about whatever they wanted. A further advantage of giving choices is that it will foster students' independence and responsibility [21]. Even though they are just suggestions, these topics and accounts of personal experience are valuable as an initial way of getting students to speak at greater length, to develop and structure their speech, and to practice linking the various parts together [22].

\subsection{How to Present Lexical Phrases to Language Learners}

Lexical phrases were presented to language learners in several ways. Some are presented through mini lectures and some through simulated public speaking situations or activities. These include speaking connectors to buy time in speaking such as First and foremost, I'd like to talk about..., First of all etc. The research instrument is retrospective interviews, asking the research participants why they paused the way they did. Each was asked to give retrospective responses one by one, in Thai, right after their speeches were given and after listening to their own audio recordings.

\subsection{Research Instruments}

Two research instruments were used in this research. They are the tapescripts of the speech and the retrospective interviews.

1. The tapescripts of the speech: Tapescripts were transcribed from audio recordings of the research participants' speech in English to see where they paused and how long they paused.

2. The retrospective interviews: Each research participant was asked to give retrospective responses one by one, in Thai, after their speeches and after listening to their own recordings. Retrospective interviews were conducted to see why they paused. These excerpts from this instrument were used to qualitatively support and clarify the data from their speeches that show how much and how long they paused. The retrospective interviews were conducted by asking for the reasons for each pause.

\section{Results and Discussion}

\subsection{Data Presentation}

From the speech and tapescripts, if lexical phrases can be identified in the tapescripts of the research participants' speech then we can see where they interrupted lexical phrases in some way, for example, by pausing in the middle of lexical phrases. If the research participants are doing that then it indicates that they are not using lexical phrases. It suggested that the research participants are speaking word by word, otherwise they will not be interrupting lexical phrases. The purpose of teaching lexical phrases is to get the research participants away from speaking word by word. We can attempt to identify lexical phrases in the tapescripts and look at where the research participants interrupt lexical phrases. Then we can look at the proportion of lexical phrases which are interrupted. The results will be presented by looking at the following:

- The proportion of taught lexical phrases

- The proportion of untaught lexical phrases

- The proportion of lexical phrases which were interrupted

- The proportion of lexical phrases which were uninterrupted

- The proportion of taught lexical phrases which were interrupted

- The proportion of taught lexical phrases which were uninterrupted

- The proportion of untaught lexical phrases which were interrupted

- The proportion of untaught lexical phrases which were uninterrupted

Table 2. The Effects Lexical Phrases have on Learners' Speaking from Speech 1 to 12 in Total

Lexical phrases in total $=395$

\begin{tabular}{|c|c|c|c|c|c|}
\hline \multirow{2}{*}{ Categories } & \multicolumn{2}{|c|}{ Taught } & \multicolumn{2}{c|}{ Untaught } & \multirow{2}{*}{ Total } \\
\cline { 2 - 5 } & $\begin{array}{c}\text { \% of total lexical } \\
\text { phrases }\end{array}$ & $\begin{array}{c}\text { \% of taught lexical } \\
\text { phrases }\end{array}$ & $\begin{array}{c}\text { \% of total lexical } \\
\text { phrases }\end{array}$ & $\begin{array}{c}\text { \% of untaught } \\
\text { lexical phrases }\end{array}$ & 17.12 \\
\hline Interrupted & 7.65 & 10.43 & 9.47 & 19.14 & 82.88 \\
\hline Uninterrupted & 42.44 & 89.57 & 40.44 & 80.86 & 100 \\
\hline Total & 50.09 & 100.00 & 49.91 & 100.00 & 100 \\
\hline
\end{tabular}


From 395 lexical phrases in total in Table 2, taught lexical phrases are being interrupted more than untaught lexical phrases. However, there is very little difference between the percentage of the taught and the untaught lexical phrases that were interrupted. Uninterrupted lexical phrases occurred in the speeches slightly more than interrupted lexical phrases which show the student is speaking more than speaking word by word. Teaching lexical phrases therefore seems not to help as much as was expected. Following are the respective results of the effects lexical phrases have on learners' speaking from speech 1 to 12 in details.

Table 3. The Effects Lexical Phrases have on Learners' Speaking from Speech 1 to 12

Speech 1: Lexical phrases in total $=75$

\begin{tabular}{|c|c|c|c|c|c|}
\hline \multirow[b]{2}{*}{ Categories } & \multicolumn{2}{|c|}{ Taught } & \multicolumn{2}{|c|}{ Untaught } & \multirow[b]{2}{*}{ Total } \\
\hline & $\begin{array}{c}\% \text { of total lexical } \\
\text { phrases }\end{array}$ & $\begin{array}{c}\% \text { of taught lexical } \\
\text { phrases }\end{array}$ & $\begin{array}{c}\% \text { of total lexical } \\
\text { phrases }\end{array}$ & $\begin{array}{l}\% \text { of untaught } \\
\text { lexical phrases }\end{array}$ & \\
\hline Interrupted & 17.72 & 22.76 & 3.28 & 18.59 & 24.00 \\
\hline Uninterrupted & 62.65 & 77.24 & 16.35 & 81.41 & 79.00 \\
\hline Total & 80.37 & 100.00 & 19.63 & 100.00 & 100.00 \\
\hline
\end{tabular}

Speech 2: Lexical phrases in total $=66$

\begin{tabular}{|c|c|c|c|c|c|}
\hline \multirow{2}{*}{ Categories } & \multicolumn{2}{|c|}{ Taught } & \multicolumn{2}{|c|}{ Untaught } & \multirow{2}{*}{ Total } \\
\cline { 2 - 5 } & $\begin{array}{c}\text { \% of total lexical } \\
\text { phrases }\end{array}$ & $\begin{array}{c}\text { \% of taught lexical } \\
\text { phrases }\end{array}$ & $\begin{array}{c}\text { \% of total lexical } \\
\text { phrases }\end{array}$ & $\begin{array}{c}\text { \% of untaught } \\
\text { lexical phrases }\end{array}$ & 31.16 \\
\hline Interrupted & 16.30 & 18.76 & 14.86 & 19.59 & 68.84 \\
\hline Uninterrupted & 52.69 & 81.24 & 16.15 & 80.41 & 100.00 \\
\hline Total & 68.99 & 100.00 & 31.01 & 100.00 & \\
\hline
\end{tabular}

Speech 3: Lexical phrases in total $=53$

\begin{tabular}{|c|c|c|c|c|c|}
\hline \multirow{2}{*}{ Categories } & \multicolumn{2}{|c|}{ Taught } & \multicolumn{2}{|c|}{ Untaught } & \multirow{2}{*}{ Total } \\
\cline { 2 - 5 } & $\begin{array}{c}\text { \% of total lexical } \\
\text { phrases }\end{array}$ & $\begin{array}{c}\text { \% of taught lexical } \\
\text { phrases }\end{array}$ & $\begin{array}{c}\text { \% of total lexical } \\
\text { phrases }\end{array}$ & $\begin{array}{c}\text { \% of untaught } \\
\text { lexical phrases }\end{array}$ & 24.66 \\
\hline Interrupted & 17.92 & 20.72 & 6.74 & 17.86 & 75.34 \\
\hline Uninterrupted & 53.67 & 79.28 & 21.67 & 82.14 & 100.00 \\
\hline Total & 71.59 & 100.00 & 28.41 & 100.00 & 2 \\
\hline
\end{tabular}

Speech 4: Lexical phrases in total $=42$

\begin{tabular}{|c|c|c|c|c|c|}
\hline \multirow{2}{*}{ Categories } & \multicolumn{2}{|c|}{ Taught } & \multicolumn{2}{|c|}{ Untaught } & \multirow{2}{*}{ Total } \\
\cline { 2 - 5 } & $\begin{array}{c}\text { \% of total lexical } \\
\text { phrases }\end{array}$ & $\begin{array}{c}\text { \% of taught lexical } \\
\text { phrases }\end{array}$ & $\begin{array}{c}\text { \% of total lexical } \\
\text { phrases }\end{array}$ & $\begin{array}{c}\text { \% of untaught } \\
\text { lexical phrases }\end{array}$ & 21.35 \\
\hline Interrupted & 17.87 & 16.99 & 3.48 & 33.33 & 78.65 \\
\hline Uninterrupted & 69.79 & 83.03 & 8.86 & 66.67 & 100.00 \\
\hline Total & 87.66 & 100.00 & 12.34 & 100.00 & \\
\hline
\end{tabular}

Speech 5: Lexical phrases in total $=38$

\begin{tabular}{|c|c|c|c|c|c|}
\hline \multirow{2}{*}{ Categories } & \multicolumn{2}{|c|}{ Taught } & \multicolumn{2}{|c|}{ Untaught } & \multirow{2}{*}{ Total } \\
\cline { 2 - 5 } & $\begin{array}{c}\text { \% of total lexical } \\
\text { phrases }\end{array}$ & $\begin{array}{c}\text { \% of taught lexical } \\
\text { phrases }\end{array}$ & $\begin{array}{c}\text { \% of total lexical } \\
\text { phrases }\end{array}$ & $\begin{array}{c}\text { \% of untaught } \\
\text { lexical phrases }\end{array}$ & 17.36 \\
\hline Interrupted & 6.62 & 10.41 & 10.74 & 19.14 & 82.64 \\
\hline Uninterrupted & 46.62 & 89.57 & 36.02 & 80.86 & 100.00 \\
\hline Total & 53.24 & 100.00 & 46.76 & 100.00 & 100 \\
\hline
\end{tabular}


Speech 6: Lexical phrases in total $=27$

\begin{tabular}{|c|c|c|c|c|c|}
\hline \multirow{2}{*}{ Categories } & \multicolumn{2}{|c|}{ Taught } & \multicolumn{2}{|c|}{ Untaught } & \multirow{2}{*}{ Total } \\
\cline { 2 - 5 } & $\begin{array}{c}\text { \% of total lexical } \\
\text { phrases }\end{array}$ & $\begin{array}{c}\text { \% of taught lexical } \\
\text { phrases }\end{array}$ & $\begin{array}{c}\text { \% of total lexical } \\
\text { phrases }\end{array}$ & $\begin{array}{c}\text { \% of untaught } \\
\text { lexical phrases }\end{array}$ & \\
\hline Interrupted & 15.01 & 22.58 & 5.39 & 16.67 & 20.40 \\
\hline Uninterrupted & 67.84 & 77.42 & 11.76 & 83.33 & 79.60 \\
\hline Total & 82.85 & 100.00 & 17.15 & 100.00 & 100.00 \\
\hline
\end{tabular}

Speech 7: Lexical phrases in total $=19$

\begin{tabular}{|c|c|c|c|c|c|}
\hline \multirow{2}{*}{ Categories } & \multicolumn{2}{|c|}{ Taught } & \multicolumn{2}{c|}{ Untaught } & \multirow{2}{*}{ Total } \\
\cline { 2 - 5 } & $\begin{array}{c}\text { \% of total lexical } \\
\text { phrases }\end{array}$ & $\begin{array}{c}\text { \% of taught lexical } \\
\text { phrases }\end{array}$ & $\begin{array}{c}\text { \% of total lexical } \\
\text { phrases }\end{array}$ & $\begin{array}{c}\text { \% of untaught } \\
\text { lexical phrases }\end{array}$ & 20.77 \\
\hline Interrupted & 14.40 & 28.93 & 6.37 & 18.76 & 79.23 \\
\hline Uninterrupted & 64.47 & 71.07 & 14.76 & 81.24 & 100 \\
\hline Total & 78.87 & 100.00 & 21.13 & 100.00 & \\
\hline
\end{tabular}

Speech 8: Lexical phrases in total $=15$

\begin{tabular}{|c|c|c|c|c|c|}
\hline \multirow{2}{*}{ Categories } & \multicolumn{2}{|c|}{ Taught } & \multicolumn{2}{|c|}{ Untaught } & \multirow{2}{*}{ Total } \\
\cline { 2 - 5 } & $\begin{array}{c}\text { \% of total lexical } \\
\text { phrases }\end{array}$ & $\begin{array}{c}\text { \% of taught lexical } \\
\text { phrases }\end{array}$ & $\begin{array}{c}\text { \% of total lexical } \\
\text { phrases }\end{array}$ & $\begin{array}{c}\text { \% of untaught } \\
\text { lexical phrases }\end{array}$ & 20.75 \\
\hline Interrupted & 12.28 & 15.05 & 8.47 & 20.79 & 79.25 \\
\hline Uninterrupted & 68.39 & 84.95 & 10.86 & 79.21 & 100 \\
\hline Total & 80.67 & 100.00 & 19.33 & 100.00 & \\
\hline
\end{tabular}

Speech 9: Lexical phrases in total $=16$

\begin{tabular}{|c|c|c|c|c|c|}
\hline \multirow{2}{*}{ Categories } & \multicolumn{2}{|c|}{ Taught } & \multicolumn{2}{c|}{ Untaught } & \multirow{2}{*}{ Total } \\
\cline { 2 - 5 } & $\begin{array}{c}\text { \% of total lexical } \\
\text { phrases }\end{array}$ & $\begin{array}{c}\text { \% of taught lexical } \\
\text { phrases }\end{array}$ & $\begin{array}{c}\text { \% of total lexical } \\
\text { phrases }\end{array}$ & $\begin{array}{c}\text { \% of untaught } \\
\text { lexical phrases }\end{array}$ & 19.94 \\
\hline Interrupted & 15.95 & 20.81 & 3.99 & 17.08 & 80.06 \\
\hline Uninterrupted & 60.68 & 79.18 & 19.37 & 82.92 & 100 \\
\hline Total & 76.64 & 100.00 & 23.36 & 100.00 & \\
\hline
\end{tabular}

Speech 10: Lexical phrases in total $=13$

\begin{tabular}{|l|l|l|l|l|l|}
\hline \multirow{2}{*}{ Categories } & \multicolumn{2}{|l|}{ Taught } & \multicolumn{2}{l|}{ Untaught } & \multirow{2}{*}{ Total } \\
\cline { 2 - 5 } & $\begin{array}{l}\text { \% of total lexical } \\
\text { phrases }\end{array}$ & $\begin{array}{l}\text { \% of taught lexical } \\
\text { phrases }\end{array}$ & $\begin{array}{l}\text { \% of total lexical } \\
\text { phrases }\end{array}$ & $\begin{array}{l}\text { \% of untaught } \\
\text { lexical phrases }\end{array}$ & \\
\hline Interrupted & 15.59 & 26.00 & 5.16 & 0 & 20.75 \\
\hline Uninterrupted & 60.52 & 74.00 & 18.73 & 100.00 & 79.25 \\
\hline Total & 76.11 & 100.00 & 23.89 & 100.00 & 100 \\
\hline
\end{tabular}

Speech 11: Lexical phrases in total $=17$

\begin{tabular}{|c|c|c|c|c|c|}
\hline \multirow{2}{*}{ Categories } & \multicolumn{2}{|c|}{ Taught } & \multicolumn{2}{c|}{ Untaught } & \multirow{2}{*}{ Total } \\
\cline { 2 - 5 } & $\begin{array}{c}\text { \% of total lexical } \\
\text { phrases }\end{array}$ & $\begin{array}{c}\text { \% of taught lexical } \\
\text { phrases }\end{array}$ & $\begin{array}{c}\text { \% of total lexical } \\
\text { phrases }\end{array}$ & $\begin{array}{c}\text { \% of untaught } \\
\text { lexical phrases }\end{array}$ & 31.66 \\
\hline Interrupted & 28.28 & 32.69 & 3.38 & 19.95 & 68.34 \\
\hline Uninterrupted & 60.04 & 67.30 & 8.30 & 80.05 & 100 \\
\hline Total & 88.32 & 100.00 & 11.68 & 100.00 & 100 \\
\hline
\end{tabular}


Speech 12: Lexical phrases in total $=14$

\begin{tabular}{|c|c|c|c|c|c|}
\hline \multirow{2}{*}{ Categories } & \multicolumn{2}{|c|}{ Taught } & \multicolumn{2}{c|}{ Untaught } & \multirow{2}{*}{ Total } \\
\cline { 2 - 5 } & $\begin{array}{c}\text { \% of total lexical } \\
\text { phrases }\end{array}$ & $\begin{array}{c}\text { \% of taught lexical } \\
\text { phrases }\end{array}$ & $\begin{array}{c}\text { \% of total lexical } \\
\text { phrases }\end{array}$ & $\begin{array}{c}\text { \% of untaught } \\
\text { lexical phrases }\end{array}$ & 33.35 \\
\hline Interrupted & 29.70 & 32.47 & 3.65 & 50.00 & 66.65 \\
\hline Uninterrupted & 65.01 & 67.57 & 1.64 & 50.00 & 100 \\
\hline Total & 94.71 & 100.00 & 5.29 & 100.00 & \\
\hline
\end{tabular}

Table 3 presents that in every speech from speech 1 to 12 , uninterrupted lexical phrases occurred in the research participants' speeches more than interrupted lexical phrases which show that they used the taught lexical phrases in speech more than speaking word by word.

\subsection{Reasons for Pausing}

From the retrospective interviews, the data were used to generate qualitative data on reasons why the research participants pause. Excerpts from this instrument were used to qualitatively support the primary data from the speech by grouping the comments into similar categories and tallying them. Table 4 below shows the results, implying reasons for pausing in interrupted lexical phrases throughout speech 1 to 12 .

Table 4. Reasons for Pausing from Speech 1 to 12

\begin{tabular}{|c|c|}
\hline Reasons for Pausing & $\mathbf{\%}$ \\
\hline Recalling & 32.02 \\
\hline $\begin{array}{c}\text { Hesitation due to Self-repair/ } \\
\text { Self-correction }\end{array}$ & 25.18 \\
\hline Search for Grammar Form & 18.56 \\
\hline Search for Vocabulary & 12.39 \\
\hline Search for Idea & 10.72 \\
\hline Natural Breathing & 1.13 \\
\hline Total & 100 \\
\hline
\end{tabular}

Overall, the results of table 4 show that students pause in order to search for content more than to search for language structure. The top reason for pausing is recalling. This result suggested that, because lexical phrases come readymade, the students need not to focus and spend time searching for language structure.

\section{Conclusions and Application}

To help the students use lexical phrases they have learned, the teacher may do some training of lexical phrases or recall information which is the main reason research participants interrupted lexical phrases according to this research. In addition, the teacher may provide time in order to allow the students to practice using and applying lexical phrases both with and without guidance from the teacher. One way of encouraging the students to use lexical phrases is through the activity of "Confidence with Phrases' [23]. In this activity, the teacher will tell a short story with lexical phrases that are taught. Afterwards, the students will take turns to tell similar stories but from their own experience, using lexical phrases. The opportunity of using lexical phrases through this activity helps the students to become familiar with using lexical phrases. This allows the students to be able to use lexical phrases in public speaking.

Another activity to get the students to practice using lexical phrases is through reading aloud. The observations show the problems of pausing too many times, many pauses took a long time and were in the wrong places. The tapescripts show that the research participants sometimes do not pause according to meaning units or do not pause according to lexical phrases. It implies that the research participants do not focus on meaning units enough. The students need teaching material, something that the teacher can point out and that the students can see visually where meaningful units start and end. Practicing reading out loud first before doing the speech in meaningful units may solve the problem. Reading out loud is to read aloud from a written text and pause according to meaningful units. In reading aloud, the teacher can point out meaning units as lexical phrases from the written form. The learners tend to see the meaning units more obviously than in other teaching activities, first, because it is written out and second, because it is used in context. For teaching lexical phrases with reading aloud, the teacher could read the speech note as a demonstration, show where the pauses are, and explain the meaningful units for the students to see sentence by sentence. The students can repeat. The steps of training should start with short, simple sentences to longer and more complicated ones. When the students are ready, the teacher could move on to text length.

Other activities might also be introduced, for example, placing lexical phrases into context [24]. For training in placing lexical phrases into a context strategy, the students will be provided with a list of lexical phrases. Then they will be asked to make sentences or to create their own context in which they can use these lexical phrases. Learning lexical phrases by using them repeatedly on their own meaningful sentences or context can help the students to understand, remember, apply and use them efficiently. Eventually, the student will stop speaking word for word 
and start using lexical phrases in their speech. Teachers should guide the students to make oral productions by lexical phrases so they could complete the default communication tasks and communicative activities like in public speaking [25].

From conducting this research study, the researcher notices that just teaching lexical phrases does not cover the students' needs of language input to get by in public speaking. They need transitional phrases, which in a way are also qualified as lexical phrases but act as the transitional phrases from one idea to another. Another aspect worth mentioning is the use of familiar words instead of using big, pretentious ones which are a burden to understanding.

Transitions are words or phrases that indicate when a speaker has just completed one thought and is moving on to another thought. Technically, the transitions state both the idea the speaker is leaving and the idea he is coming up to talk about. They are the reminder for the listener of the thoughts the speaker wants to complete as well as revealing the thoughts about to be introduced to. Familiar words also count as familiar phrases in speaking. One of the biggest barriers to clear speech is using big, unordinary words where short, simple ones will do.

The researcher found that the number of interrupted lexical phrases was reduced through the research. From the results shown, the researcher would like to suggest that students learn lexical phrases in public speaking. Because of the improvement in the students' speaking, it seems that lexical phrases can be taught and that they could help with fluency when delivering speeches.

\section{Acknowledgements}

I would like to thank my wonderful research participants for their time in participating in this research. I would also like to thank my university and the English Department for their support in every way.

\section{REFERENCES}

[1] Chen Xin. "Lexical Chunk Instruction and Acquisition of Second Language," Journal of Fujian Institute of Education, vol. 4, no. 7, pp. 87-90, 2004. http://caod.oriprobe.com/articles/8067539/_Lexical_Chunk_ Instruction_and_Acquisition_of_Second_Language.htm

[2] Diao, L. “A Survey of Chinese English Majors' Chunk Competence," Journal of PLA University of Foreign Languages, vol. 27, no. 4, pp.35-38, 2004. http://caod.oriprobe.com/articles/7628347/A_Survey of C hinese_English_Majors_Chunk_Competence.htm

[3] Xu, J. \& Xu, Z. "Discourse Management Chunks in Chinese College Learners' English Speech," Foreign Language
Teaching and Research, vol. 40, no. 6, pp. 437-443, 2007. https://caod.oriprobe.com/articles/13280533/Discourse_M anagement_Chunks_in_Chinese_college_lea.htm

[4] $\mathrm{Pu}, \mathrm{J}$. "Colligation, Collocation and Chunk in ESL Vocabulary Teaching and Learning," Foreign Language Teaching and Research, vol. 37, no. 6, pp. 438-445, 2003. https://caod.oriprobe.com/articles/6385800/Colligation_c ollocation_and_chunk_in_ESL_vocabulary_teaching_and _lea.htm

[5] Chen Yi. "On Chunking Approach in ELT," Journal of Fujian Medical University, vol. 38, no. 4, pp. 71-73, 2006. https://www.semanticscholar.org/paper/On-Chunking-App roach-in-ELT-Yi/df1054ead8c48499275b4a9f79c7d81fee9 c9ec1

[6] Wang, L. \& Zhang, Y. "A Corpus-based Study on Chunks in English Argumentative Writing of Chinese EFL Learners," Computer-assisted Foreign Language Education, vol. 30, no. 4, pp. 36-41, 2006. https:/en.cnki.com.cn/Article_en/CJFDTotal-OUTL20090 2033.htm

[7] Carter, R. \& McCarthy, M. "Vocabulary and Language Teaching, Longman, Singapore", 1988.

[8] Pawley, A. K. \& Syder. F. H. "Language and Communication: The One Clause at a Time Hypothesis, Longman, Singapore", 1983.

[9] Lucas, S. E. "The Art of Public Speaking", McGraw Hill, New York, 2007.

[10] Nattinger, J. R. \& DeCarrico, J. S. "Lexical Phrases and Language Teaching”, Oxford University Press, Hong Kong, 1992.

[11] Skehan, P. A "Cognitive Approach to Language Learning", Oxford University Press, Oxford, 1998.

[12] Schmidt, R. "The Role of Consciousness in Second Language Learning," Applied Linguistics, vol. 11, no. 2, pp. 17-46, 1990.https://nflrc.hawaii.edu/PDFs/SCHMIDT\%20 The $\% 20$ role $\% 20$ of $\% 20$ consciousness $\% 20$ in $\% 20$ second $\% 2$ 0language $\% 201$ earning.pdf

[13] Wray, A. "Formulaic Language and the Lexicon", Cambridge University Press, Cambridge, 2002.

[14] Lewis, M. "The Lexical Approach", Language Teaching Publications, London, 1993.

[15] Nattinger, J. R. "A Lexical Phrase Grammar for ESL," TESOL Quarterly, vol. 14, no. 3, pp. 341, 1980. https://doi.org/10.2307/3586598

[16] Lewis, M. "Implementing the Lexical Approach", Language Teaching Publications, London, 1997.

[17] Yang, Y. \& Wen, Q. "Experimental Study on Lexical Approach and Language Productive Competence," Journal of Anhui Electrical Engineering Professional Technique College, vol. 10, no. 2, pp. 86-91, 2010 http://caod.oriprobe.com/articles/24043459/Experimental_ Study_on_Lexical_Approach_and_Language_Productive_ Compete. $\bar{h}$ tm

[18] Chambers, F. "What Do We Mean By Fluency," System, vol. 25 , no. 4 pp. $535-544$, 1997. https://doi.org/10.1016/S 0346-251X(97)00046-8 
[19] Yuan, W. "The Use of the Theory about Chunks of Language in TCFL," Language Teaching and Linguistic Studies, vol. 30, no. 4, pp. 54-61, 2008. $\mathrm{https}$ :/caod.oriprobe.com/articles/22811310/The_Use_of_t he_Theory_about_Chunks_of_Language_in_.htm

[20] Bygate, M. "Speaking”, Oxford University Press, Oxford, 1987.

[21] Gower, R., Phillips, D. \& Walters. S. "Teaching Practice Handbook", Heineman, Oxford, 1995.
[22] Hedge, T. "Teaching and Learning in the Language Classroom”, Oxford University Press, Oxford, 2000.

[23] Davis, P. \& Rinvolucri, M. "The Confidence Book", Longman, London, 1990.

[24] Oxford, R. L. "Language Learning Strategies", Newbury House, New York, 1990.

[25] Liu, J. "Lexical Chunks and College English Teaching," Shandong Foreign Language Teaching Journal, vol. 6, no. 4, pp. 88-90, 2006. https://caod.oriprobe.com/articles/107593 32/Lexical_Chunks_and_College_English_Teaching.htm 